\title{
Influence of Hydrothermal Pretreatment Temperature on the Hydration Properties and Direct Carbonation Efficiency of Al-Rich Ladle Furnace Refining Slag
}

\author{
Yi Huang ${ }^{1, *}$ and Guo Xiong ${ }^{2}$ \\ 1 School of Materials and Chemical Engineering, Hunan City University, Yiyang 413002, China \\ 2 Hunan Hualin Xiangtan Iron and Steel Co., Ltd., Xiangtan 411101, China; xgsz50@163.com \\ * Correspondence: Huangyi@hncu.edu.cn
}

Citation: Huang, Y.; Xiong, G. Influence of Hydrothermal

Pretreatment Temperature on the Hydration Properties and Direct Carbonation Efficiency of Al-Rich Ladle Furnace Refining Slag. Processes 2021, 9, 1458. https://doi.org/ $10.3390 /$ pr 9081458

Academic Editor: Federica Raganati

Received: 29 July 2021

Accepted: 19 August 2021

Published: 21 August 2021

Publisher's Note: MDPI stays neutral with regard to jurisdictional claims in published maps and institutional affiliations.

Copyright: () 2021 by the authors. Licensee MDPI, Basel, Switzerland. This article is an open access article distributed under the terms and conditions of the Creative Commons Attribution (CC BY) license (https:// creativecommons.org/licenses/by/ $4.0 /)$.

\begin{abstract}
The influence of hydrothermal pretreatment temperature on the hydration products and carbonation efficiency of Al-rich LF slag was investigated. The results showed that the carbonation efficiency was strongly dependent on the morphology of hydration products and the hydration extent of the raw slag. Hydrothermal pretreatment at $20^{\circ} \mathrm{C}$ or $80^{\circ} \mathrm{C}$ favored the formation of flakeshaped products with a higher specific surface area and therefore resulted in a higher $\mathrm{CO}_{2}$ uptake of $20^{\circ} \mathrm{C}$ and $80{ }^{\circ} \mathrm{C}$-pretreated slags (13.66 wt \% and $10.82 \mathrm{wt} \%$, respectively). However, hydrothermal pretreatment at $40{ }^{\circ} \mathrm{C}, 60^{\circ} \mathrm{C}$ or $100{ }^{\circ} \mathrm{C}$ led to the rhombohedral-shaped calcite layer surrounding the unreacted core of the raw slag and the formation of fewer flake-shaped products, resulting in a lower $\mathrm{CO}_{2}$ uptake of $40{ }^{\circ} \mathrm{C}, 60^{\circ} \mathrm{C}$ and $100{ }^{\circ} \mathrm{C}$-pretreated slags $(9.21 \mathrm{wt} \%, 9.83 \mathrm{wt} \%$, and $6.84 \mathrm{wt} \%$, respectively).
\end{abstract}

Keywords: LF slag; hydrothermal pretreatment; temperature; hydration products; $\mathrm{CO}_{2}$ uptake

\section{Introduction}

The growth of global greenhouse gas emissions was $2.0 \%$ in 2018 and there is no sign that any of these emissions are peaking yet. The six largest emitters of greenhouse gases, together accounting for $62 \%$ globally, are China (26\%), the United States (13\%), the European Union (more than $8 \%$ ), India (7\%), the Russian Federation (5\%), and Japan (almost 3\%) [1]. China's carbon emission peak is a matter of international focus. Recently, China made a solemn promise to peak its carbon dioxide emission by 2030 and achieve carbon neutrality by 2060. Some of the main measures China will use to reduce $\mathrm{CO}_{2}$ emissions over next 10 years are: changing energy and industrial structures, transforming the development mode, promoting clean energy, and appropriately increasing carbon sequestration ability. Among the current $\mathrm{CO}_{2}$ sequestration routes, mineral carbonation is regarded as a potential technology because of its advantages; it is environmentally benign, it enables the permanent trapping of $\mathrm{CO}_{2}$ in the form of carbonate, and it does not require post-storage surveillance for $\mathrm{CO}_{2}$ leakage [2]. In general, mineral carbonation can be divided into two categories, namely direct carbonation and indirect carbonation. Direct mineral carbonation is accomplished through the reaction of a solid alkaline mineral with $\mathrm{CO}_{2}$, either in gaseous or in aqueous phase [3].

Alkaline solid wastes such as red mud, steel slag, blast furnace slag, fly ash, etc., are used for direct mineral carbonation as efficient and economically available capturers of $\mathrm{CO}_{2}$ [4-9]. For the direct mineral carbonation of steel slag, the formation of an increasingly thick and dense carbonate layer surrounding the unreacted core of the solid particle hinders further carbonation and results in the lower $\mathrm{CO}_{2}$ capture capacity [10]. In our previous study [11], the improvement in the direct carbonation efficiency of Al-rich ladle furnace refining slag (LF slag) by hydrothermal pretreatment was investigated. The results showed that after hydrothermal pretreatment at $80{ }^{\circ} \mathrm{C}$, the morphology of $\mathrm{Ca}_{12} \mathrm{Al}_{14} \mathrm{O}_{33}\left(\mathrm{C}_{12} \mathrm{~A}_{7}\right)$ in 
the slag transformed from separated particles to the flake-shaped $\mathrm{Ca}_{3} \mathrm{Al}_{2} \mathrm{O}_{6} \cdot \mathrm{xH}_{2} \mathrm{O}\left(\mathrm{C}_{3} \mathrm{AH}_{\mathrm{x}}\right)$, resulting in an increased reaction surface area and carbonation efficiency. However, this study did not discuss the effect of hydrothermal temperature on the carbonation efficiency. In fact, the hydration product of $\mathrm{C}_{12} \mathrm{~A}_{7}$ is dependent on the hydration temperature. Koplík et al. [12] reported that at $20{ }^{\circ} \mathrm{C}$ the major hydration products of $\mathrm{C}_{12} \mathrm{~A}_{7}$ were $\mathrm{Ca}_{2} \mathrm{Al}_{2} \mathrm{O}_{5} \cdot 8 \mathrm{H}_{2} \mathrm{O}\left(\mathrm{C}_{2} \mathrm{AH}_{8}\right)$ and $\mathrm{CaAl}_{2} \mathrm{O}_{4} \cdot 10 \mathrm{H}_{2} \mathrm{O}\left(\mathrm{CAH}_{10}\right)$; at $30^{\circ} \mathrm{C} \mathrm{CAH}_{10}$ disappeared and only $\mathrm{C}_{2} \mathrm{AH}_{8}$ remained; at $60{ }^{\circ} \mathrm{C}$ the only stable hydrates- $\mathrm{Ca}_{3} \mathrm{Al}_{2} \mathrm{O}_{6} \cdot 6 \mathrm{H}_{2} \mathrm{O}\left(\mathrm{C}_{3} \mathrm{AH}_{6}\right)$ and $\mathrm{Al}(\mathrm{OH})_{3}(\mathrm{AH})$ were formed. Edmonds et al. [13] stated that both $\mathrm{C}_{2} \mathrm{AH}_{8}$ and $\mathrm{CAH}_{10}$ can be produced during the hydration of $\mathrm{C}_{12} \mathrm{~A}_{7}$ at $4{ }^{\circ} \mathrm{C}$, while no trace of $\mathrm{CAH}_{10}$ was spotted when $\mathrm{C}_{12} \mathrm{~A}_{7}$ was hydrated at 20 or $40{ }^{\circ} \mathrm{C}$. Given that the morphology of the hydration product of C12A7 has a significant effect on the carbonation efficiency of LF slag and the type of hydration product produced is related to temperature, the aim of this study was to investigate the influence of hydrothermal pre-treatment temperature on the hydration properties and the carbonation efficiency of Al-rich LF slag at ambient temperature and pressure. Moreover, the relation between the morphology of the hydration product and the carbonation efficiency was clarified in this work.

\section{Materials and Methods}

\subsection{Materials}

The Al-rich LF slag used in this study was collected from the Xiangtan steel plant in Hunan province, China. The chemical composition of the slag determined by X-ray Fluorescence (XRF) is listed in Table 1. Before pretreatment, the raw slag was crushed and ground into a powder $<20$ mesh particle size. Distilled water was used in this study for slag suspension preparation.

Table 1. Chemical composition of raw slag as determined by XRF analysis.

\begin{tabular}{ccccccccc}
\hline Component & $\mathrm{CaO}$ & $\mathrm{Al}_{2} \mathrm{O}_{3}$ & $\mathrm{SiO}_{2}$ & $\mathrm{MgO}$ & $\mathrm{TiO}_{2}$ & $\mathrm{SO}_{3}$ & $\mathrm{Fe}_{2} \mathrm{O}_{3}$ & Others \\
\hline $\mathrm{wt} \%$ & 52.0056 & 23.66 & 15.83 & 4.05 & 0.90 & 2.45 & 0.54 & 0.57 \\
\hline
\end{tabular}

\subsection{Hydrothermal Pretreatment of LF Slag at Different Temperatures}

At first, the raw slag was fully mixed with water at a solid/water $(S / W)$ ratio of 1:10 in a beaker. Then, the suspension was stirred for $30 \mathrm{~min}$ at $20,40,60,80$ and $100{ }^{\circ} \mathrm{C}$ (designated as $20 \mathrm{H}, 40 \mathrm{H}, 60 \mathrm{H}, 80 \mathrm{H}$ and $100 \mathrm{H}$-slag, respectively). Next, the suspension was filtered and the obtained solid was sufficiently washed and dried to a constant weight at $105^{\circ} \mathrm{C}$ for further characterization and for the following carbonation experiment.

\subsection{Direct Aqueous Carbonation Process}

The schematic diagram of the aqueous carbonation experimental system is shown in Figure 1. The pretreated slag suspension with a solid/water ratio of 1:10 was placed in a conical flask into an electric-heated thermostatic water bath equipped with a mechanical stirrer. The temperature of the water bath was kept at $40{ }^{\circ} \mathrm{C}$. Then, $99.99 \%$ pure $\mathrm{CO}_{2}$ from the $\mathrm{CO}_{2}$ cylinder was injected into the suspension at a flow rate of $5 \mathrm{~L} / \mathrm{min}$ controlled by a flowmeter, and was simultaneously stirred for carbonation. The suspension underwent the carbonation process for $60 \mathrm{~min}$ and was then filtered. The obtained solid was dried to a constant weight at $105^{\circ} \mathrm{C}$ for further characterization. 


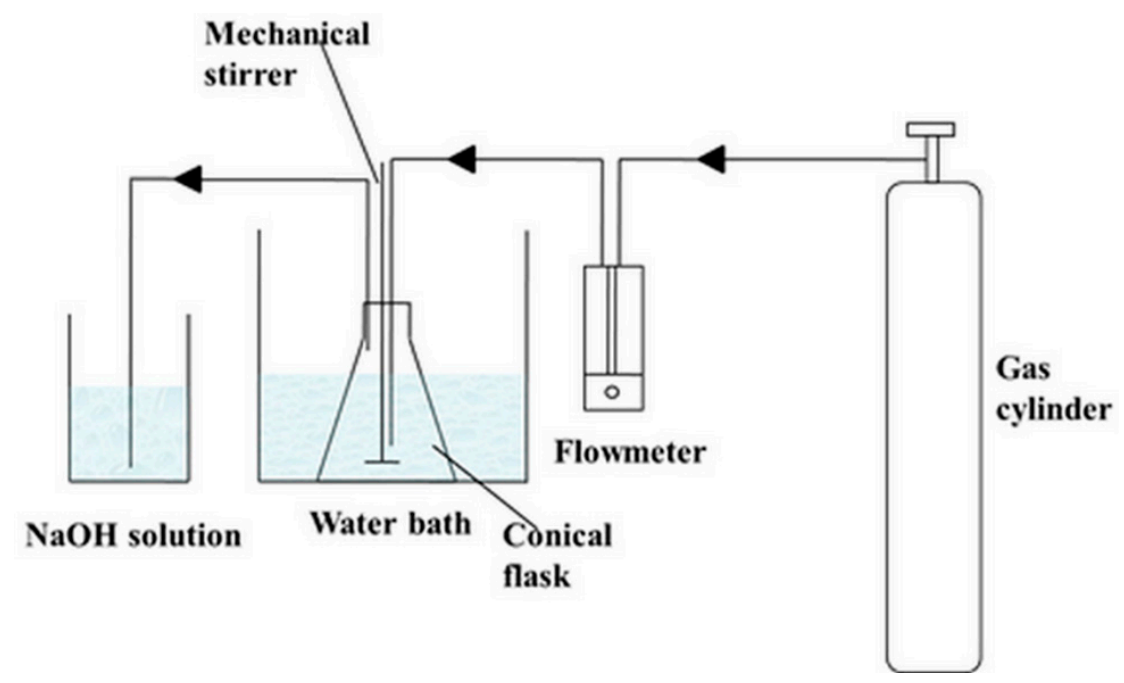

Figure 1. Schematic diagram of the aqueous carbonation experimental system.

\subsection{Characterization of Slag}

X-ray diffraction (XRD, Bruker AXS company D8 Advance, Karlsruhe, Germany) was conducted on the slags to identify their main mineral phases. The scanning range was from $5^{\circ}$ to $70^{\circ} 2 \theta$ at $2^{\circ} / \mathrm{min}$. TG-DSC analysis was performed using a METTLER TOLEDO 1600 LF thermal gravimetric analyzer. A field-emission scanning electron microscope (FESEM, Hitachi company SU8010, Tokyo, Japan) was used to characterize the morphology of the slag. The specific surface area of the slags was measured by the $\mathrm{N}_{2}$ gas adsorption Brunauer-Emmet-Teller (BET) method (ASAP 2020, Micromeritics, Norcross, GA, USA). The $\mathrm{pH}$ value of the slag suspension was determined by a PHS-3C $\mathrm{pH}$ meter.

\subsection{Analysis of Carbonation Efficiency}

In order to compare the carbonation efficiency of Al-rich LF slags under the hydrothermal pretreatment at different temperatures, the $\mathrm{CO}_{2}$ uptake of the slags was measured based on the weight fraction of the TG curve $\left(\Delta \mathrm{m}_{600-800}{ }^{\circ} \mathrm{C}\right)$ and the dry weight $(\mathrm{m})$ [14] expressed in terms of $\mathrm{CO}_{2}(\mathrm{wt} \%)$, Equation (1):

$$
\mathrm{CO}_{2}(\mathrm{wt} \%)=\frac{\Delta \mathrm{m}_{600-800}{ }^{\circ} \mathrm{C}}{\mathrm{m}} \times 100
$$

\section{Results and Discussion}

\subsection{Influence of Hydrothermal Temperature on Hydration Properties of Al-Rich LF Slag}

Figure 2 shows the XRD patterns of the raw slag and the pretreated slags. The main mineral phases of raw slag were $\mathrm{C}_{12} \mathrm{~A}_{7}$ and $\mathrm{Ca}_{2} \mathrm{SiO}_{4}\left(\mathrm{CS}_{2}\right)$. For all the slags with pretreatment, the peaks of $\mathrm{C}_{12} \mathrm{~A}_{7}$ were reduced, indicating its hydration. The $40 \mathrm{H}$-slag and $100 \mathrm{H}$-slag presented relatively more intense residual $\mathrm{C}_{12} \mathrm{~A}_{7}$ peaks than the other slags, suggesting the lower hydration extent of these two slags. For the $20 \mathrm{H}$-slag, $3 \mathrm{CaO} \cdot \mathrm{Al}_{2} \mathrm{O}_{3} \cdot \mathrm{CaCO}_{3} \cdot 11 \mathrm{H}_{2} \mathrm{O}\left(\mathrm{C}_{4} \mathrm{~A} \overline{\mathrm{C}} \mathrm{H}_{11}\right)$ was the dominant hydration product. A small amount of $\left(\mathrm{C}_{4} \mathrm{~A} \overline{\mathrm{C}} \mathrm{H}_{11}\right)$ also appeared in the $40 \mathrm{H}$-slag and $\mathrm{C}_{3} \mathrm{AH}_{6}$ was the other main product for this slag. Hydrocalumite $\left(\mathrm{Ca}_{4} \mathrm{Al}_{2}(\mathrm{OH})_{12} \mathrm{CO}_{3} \cdot 5 \mathrm{H}_{2} \mathrm{O}\right)$ was only present in the $100 \mathrm{H}$-slag, and this slag had the most intense $\mathrm{C}_{3} \mathrm{AH}_{6}$ peaks. With respect to the $60 \mathrm{H}$-slag, only $\mathrm{C}_{3} \mathrm{AH}_{6}$ crystal was found. In general, $\mathrm{C}_{3} \mathrm{AHx}, \mathrm{C}_{4} \mathrm{~A} \overline{\mathrm{C}} \mathrm{H}_{11}$, and $\mathrm{C}_{3} \mathrm{AH}_{6}$ were the main hydration products, while the other products mentioned in the "Introduction" (such as $\mathrm{CAH}_{10}$ and $\mathrm{C}_{2} \mathrm{AH}_{8}$ ) were not observed. This could be explained by the fact that $\mathrm{CAH}_{10}$ and $\mathrm{C}_{2} \mathrm{AH}_{8}$ are the transition phases and can be converted to the ultimate stable products (e.g., $\mathrm{C}_{3} \mathrm{AH}_{6}$ and $\mathrm{C}_{3} \mathrm{AH}_{\mathrm{x}}$ ), described by Equations (2)-(4), respectively [15].

$$
2 \mathrm{CAH}_{10} \rightarrow \mathrm{C}_{2} \mathrm{AH}_{8}+\mathrm{AH}_{3}+9 \mathrm{H}
$$




$$
\begin{gathered}
3 \mathrm{C}_{2} \mathrm{AH}_{8} \rightarrow 2 \mathrm{C}_{3} \mathrm{AH}_{6}+\mathrm{AH}_{3}+9 \mathrm{H} \\
3 \mathrm{C}_{2} \mathrm{AH}_{8} \rightarrow 2 \mathrm{C}_{3} \mathrm{AH}_{\mathrm{x}}+\mathrm{AH}_{3}+(21-2 \mathrm{x}) \mathrm{H}
\end{gathered}
$$

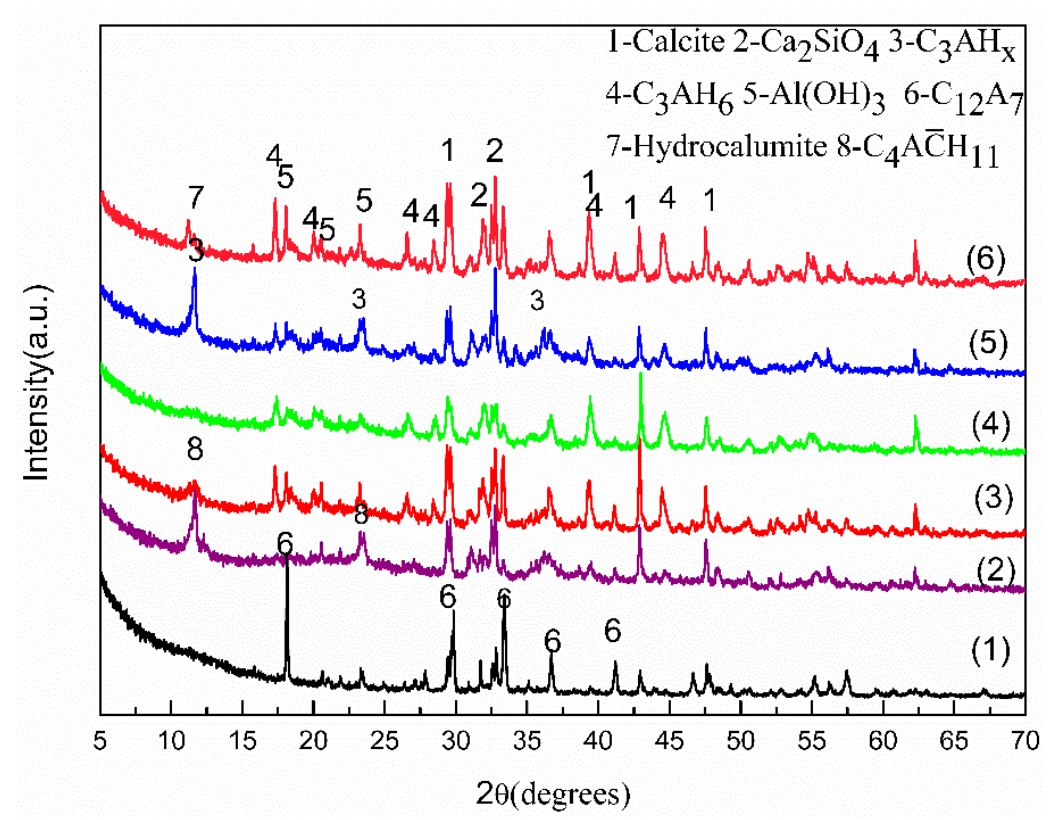

Figure 2. XRD patterns of (1) raw slag, (2) 20H-slag, (3) 40H-slag, (4) 60H-slag, (5) $80 \mathrm{H}$-slag, and (6) $100 \mathrm{H}$-slag.

Figure 3 displays the FESEM pictures of the raw slag and the pretreated slags. The raw slag appeared as irregular-shaped particles with dense and coarse surfaces (Figure 3a). After hydration at $20^{\circ} \mathrm{C}$, the slag surface became smooth due to the formation of flakeshaped $\mathrm{C}_{4} \mathrm{~A} \overline{\mathrm{C}} \mathrm{H}_{11}$ (Figure $3 \mathrm{~b}$ ). In addition, metastable hydrates in the form of hexagonal platelets [14] were observed (Figure $3 \mathrm{~b}$ ). The microstructure of the $40 \mathrm{H}$-slag presented as a mixture of $\mathrm{C}_{4} \mathrm{~A} \overline{\mathrm{C}} \mathrm{H}_{11}$, metastable hydrated hexagonal-shaped platelets [16], and unhydrated slag particles (Figure 3c). The edge of the unhydrated particles in the $40 \mathrm{H}$-slag was covered by rhombohedral-shaped $\mathrm{CaCO}_{3}$ (calcite) particles and $\mathrm{AH}$ gel with a grain size of $0.5 \mu \mathrm{m}$, which may hinder the further hydration of $\mathrm{C}_{12} \mathrm{~A}_{7}$ (Figure 3d). Once again, this verified that the thick and dense $\mathrm{CaCO}_{3}$ layer surrounding the unreacted core of the solid particle was the main cause of the low carbonation efficiency of the slag without hydrothermal pretreatment, as illustrated in our previous studies [9]. $\mathrm{CaCO}_{3}$ and $\mathrm{AH}$ gel should be generated by the indirect carbonation reaction between $\mathrm{C}_{12} \mathrm{~A}_{7}$ and $\mathrm{CO}_{2}$ in the air, which can be described by Equations (5) and (6) [17]. The occurrence of Equation (5) resulted in the alkalinity of the slag suspensions (the final $\mathrm{pH}$ values were 10.42, 10.13, $10.05,10.56$, and 10.02 for the slag suspensions treated at $20^{\circ} \mathrm{C}, 40^{\circ} \mathrm{C}, 60^{\circ} \mathrm{C}, 80^{\circ} \mathrm{C}$, and $100{ }^{\circ} \mathrm{C}$, respectively). 


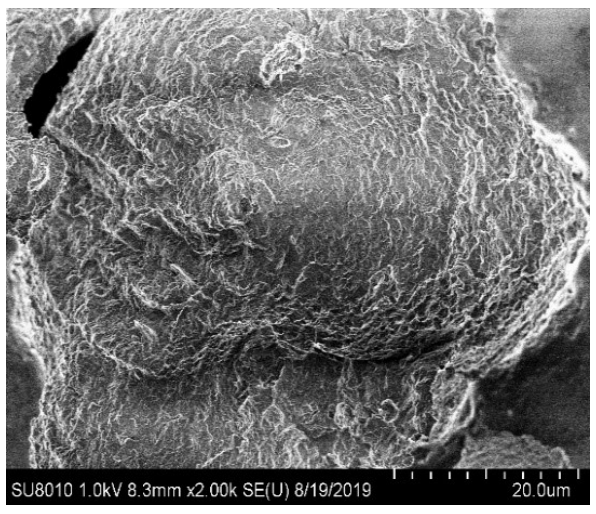

(a)

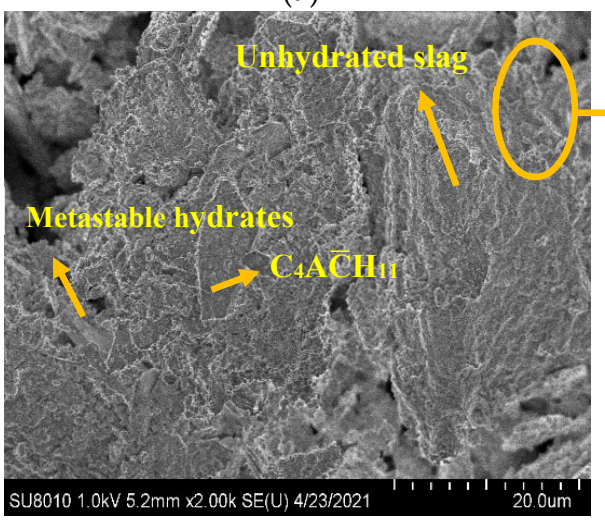

(c)

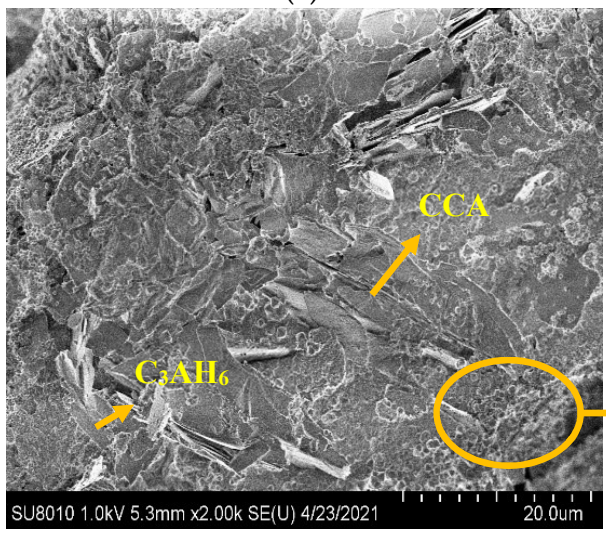

(e)

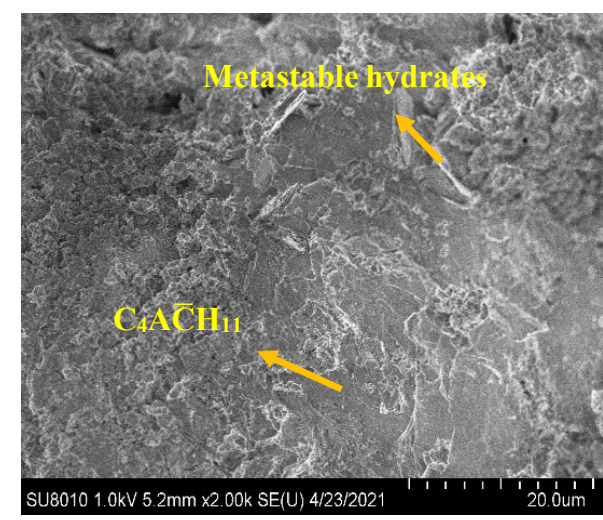

(b)

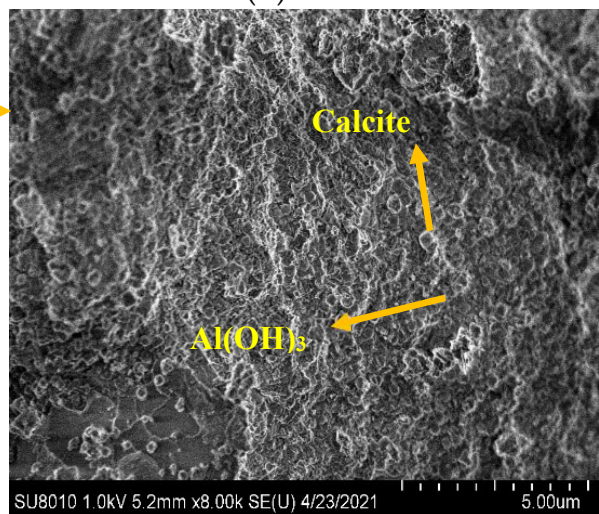

(d)

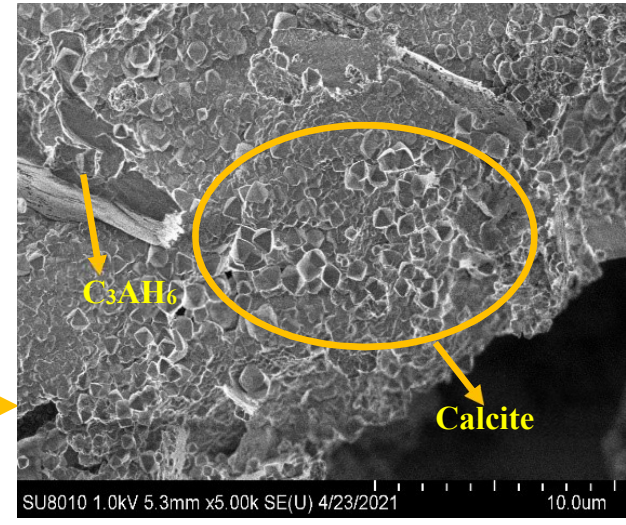

(f)

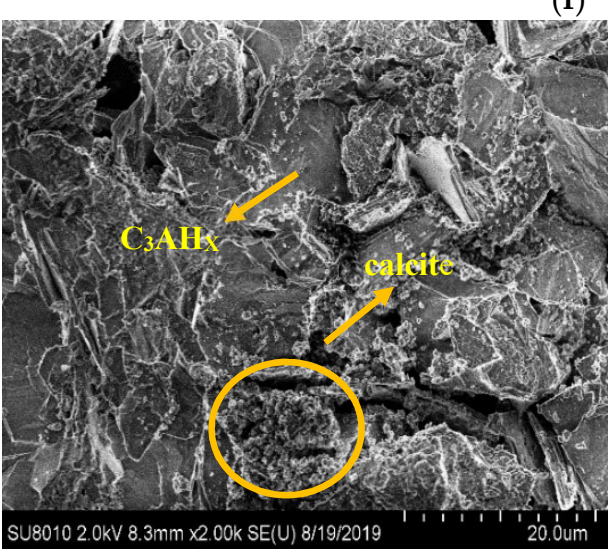

(g)

Figure 3. Cont. 


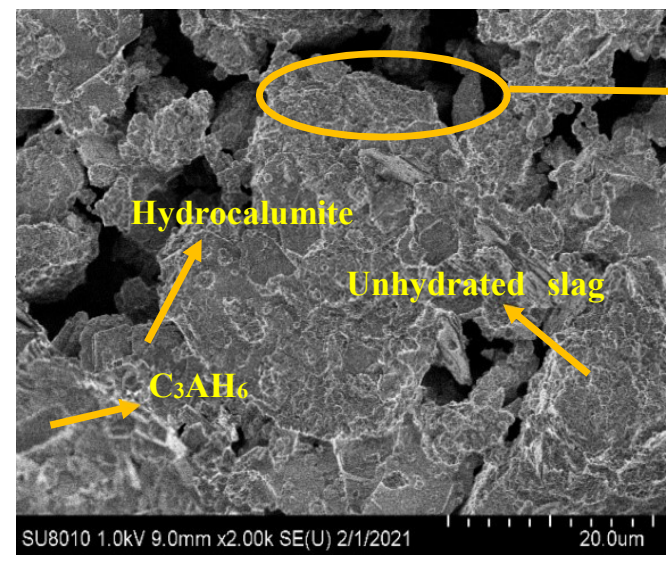

(h)

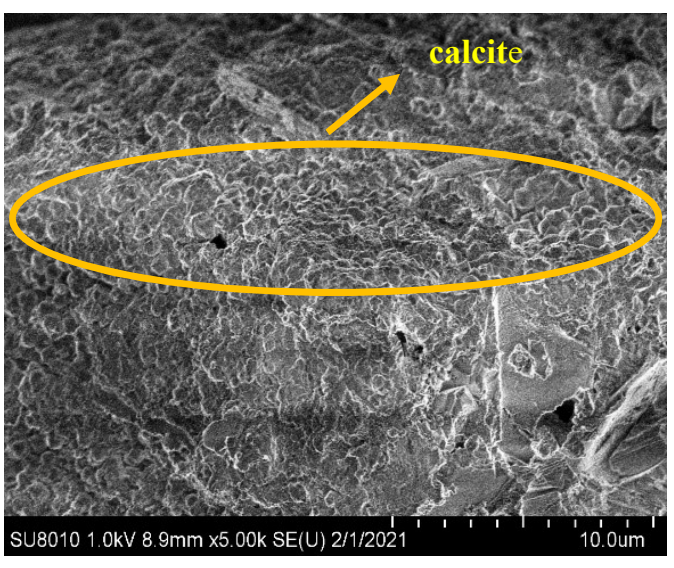

(i)

Figure 3. FESEM pictures of (a) raw slag 2000×, (b) $20 \mathrm{H}$-slag $2000 \times$, (c) $40 \mathrm{H}$-slag $2000 \times$, (d) $40 \mathrm{H}$ slag $8000 \times$, (e) $60 \mathrm{H}$-slag $2000 \times$, (f) $60 \mathrm{H}$-slag $5000 \times$, (g) $80 \mathrm{H}$ slag $2000 \times$, (h) $100 \mathrm{H}$-slag $2000 \times$ and (i) $100 \mathrm{H}$-slag $5000 \times$.

The FESEM image of the 60H-slag (Figure 3e) indicates the formation of flake-shaped and cubic hydrates that should be amorphous calcium carboaluminate (CCA) and $\mathrm{C}_{3} \mathrm{AH}_{6}$, respectively. In addition, a dense rhombohedral-shaped calcite layer covered part of the slag surface (Figure 3f). Therefore, it is assumed that CCA was formed through the reaction between $\mathrm{C}_{3} \mathrm{AH}_{6}$ and calcite $[18,19]$. This also provides an explanation for why the $20 \mathrm{H}$-slag contained large amounts of $\mathrm{C}_{4} \mathrm{~A} \overline{\mathrm{C}} \mathrm{H}_{11}$ but small amounts of calcite formation (the reaction between $\mathrm{C}_{3} \mathrm{AH}_{6}$ and calcite can be described by Equation (7) [19]). After hydration at $80{ }^{\circ} \mathrm{C}$, the morphology of the slag changed from separated particles to continuous gel (Figure $3 g$ ). The flake-shaped gel should be $\mathrm{C}_{3} \mathrm{AH}_{\mathrm{x}}$, and calcite particles were scattered on the surface of $\mathrm{C}_{3} \mathrm{AH}_{\mathrm{X}}$ in the $80 \mathrm{H}$-slag (Figure $3 \mathrm{~g}$ ). For the $100 \mathrm{H}$-slag, flake-shaped hydrocalumite and cubic $\mathrm{C}_{3} \mathrm{AH}_{6}$ particles were embedded in the unhydrated slag particles (Figure $3 \mathrm{~h}$ ), and a rhombohedral-shaped calcite layer deposited on the edge of the slag particles (Figure 3i), similarly to the $40 \mathrm{H}$ and $60 \mathrm{H}$ slag.

$$
\begin{gathered}
\mathrm{Ca}_{12} \mathrm{Al}_{14} \mathrm{O}_{33}+33 \mathrm{H}_{2} \mathrm{O} \rightarrow 12 \mathrm{Ca}^{2+}+14 \mathrm{Al}(\mathrm{OH})_{4}{ }^{-}+10 \mathrm{OH}^{-} \\
\mathrm{Ca}^{2+}+\mathrm{CO}_{2}+2 \mathrm{Al}(\mathrm{OH})_{4}{ }^{-} \rightarrow \mathrm{CaCO}_{3} \downarrow+2 \mathrm{Al}(\mathrm{OH})_{3} \downarrow+\mathrm{H}_{2} \mathrm{O} \\
\mathrm{CaCO}_{3}+\mathrm{Ca}_{3} \mathrm{Al}_{2} \mathrm{O}_{6} \cdot 6 \mathrm{H}_{2} \mathrm{O}+5 \mathrm{H}_{2} \mathrm{O} \rightarrow 3 \mathrm{CaO} \cdot \mathrm{Al}_{2} \mathrm{O}_{3} \cdot \mathrm{CaCO}_{3} \cdot 11 \mathrm{H}_{2} \mathrm{O}
\end{gathered}
$$

The BET specific surface area $\left(\mathrm{S}_{\mathrm{BET}}\right)$ of the slags were listed in Table 2 . The $\mathrm{S}_{\mathrm{BET}}$ of the $20 \mathrm{H}$-slag and the $80 \mathrm{H}$-slag was more than two times that of the raw slag, while other pretreated slags demonstrated only a slight $S_{\mathrm{BET}}$ increase compared with the raw slag. This should be attributed to the larger amount of flake-shaped hydrates in the $20 \mathrm{H}$-slag and the 80H-slag [20].

Table 2. The BET specific surface area of the pretreated slags.

\begin{tabular}{ccccccc}
\hline & Raw Slag & 20H-Slag & 40H-Slag & 60H-Slag & 80H-Slag & 100H-Slag \\
\hline SBET $\left(\mathrm{m}^{2} / \mathrm{g}\right)$ & 4.68 & 8.32 & 5.89 & 6.15 & 9.40 & 5.15 \\
\hline
\end{tabular}

Figure 4 shows the TG-DSC analysis results of the pretreated slags. The endothermic peak of around $260-270{ }^{\circ} \mathrm{C}$ denoted the decomposition of $\mathrm{Al}(\mathrm{OH})_{3}$ and appeared in all slags [19]. This peak was overlapped by the endothermic peak between $280{ }^{\circ} \mathrm{C}$ and $325{ }^{\circ} \mathrm{C}$, which was attributed to the dehydration of $\mathrm{C}_{3} \mathrm{AH}_{6}$ in the $40 \mathrm{H}$-slag, $60 \mathrm{H}$-slag, 
and $80 \mathrm{H}$-slag [18]. These results corresponded well with the XRD and FESEM analysis. The endothermic peak at $157^{\circ} \mathrm{C}$ in the $20 \mathrm{H}$-salg indicated the dehydration of $\mathrm{C}_{4} \mathrm{~A} \overline{\mathrm{C}} \mathrm{H}_{11}$ [16], while this peak became broad for the $40 \mathrm{H}$-slag due to the low crystallinity of $\mathrm{C}_{4} \mathrm{~A} \bar{C} \mathrm{H}_{11}$ [16], as was also reflected in the broad peak of XRD patterns (Figure 1). The absence of $\mathrm{C}_{4} \mathrm{~A} \bar{C} \mathrm{H}_{11}$ in the other slags can be explained by its instability in temperatures above $40{ }^{\circ} \mathrm{C}$ [19]. A very broad endothermic peak between 80 and $200{ }^{\circ} \mathrm{C}$ was observed in the $60 \mathrm{H}$-slag, generated by the dehydration of amorphous CCA [14]. The endothermic peak at $155^{\circ} \mathrm{C}$ in the $80 \mathrm{H}$-slag represented the dehydration of $\mathrm{C}_{3} \mathrm{AH}_{\mathrm{x}}$ which is close to the dehydration temperatures of $\mathrm{CAH}_{10}$ and $\mathrm{C}_{2} \mathrm{AH}_{8}$ [15]. With respect to the $100 \mathrm{H}$-slag, the dehydration of hydrocalumite was reflected in the endothermic peak around $146^{\circ} \mathrm{C}$. In general, the dehydration of hydrates mainly occurred over the temperature range of $105-325^{\circ} \mathrm{C}$, resulting in significant weight loss. The other significant weight loss region was between 600 and $800{ }^{\circ} \mathrm{C}$, which was ascribed to the $\mathrm{CaCO}_{3}$ decomposition. During the hydrothermal process, $\mathrm{C}_{12} \mathrm{~A}_{7}$ was transformed into calcium aluminates hydrate $(\mathrm{CAH}), \mathrm{CAC}, \mathrm{AH}$, and $\mathrm{CaCO}_{3}$; therefore, the mass loss ratio of the slags (See Table 3) above the temperature range of $105-800{ }^{\circ} \mathrm{C}$ should be an indicator of $\mathrm{C}_{12} \mathrm{~A}_{7}$ hydration extent. It may be concluded from the results in Table 2 that the $20 \mathrm{H}$-slag and the $80 \mathrm{H}$-slag had significantly higher hydration extent than other three slags, in good agreement with the XRD and FESEM analysis.

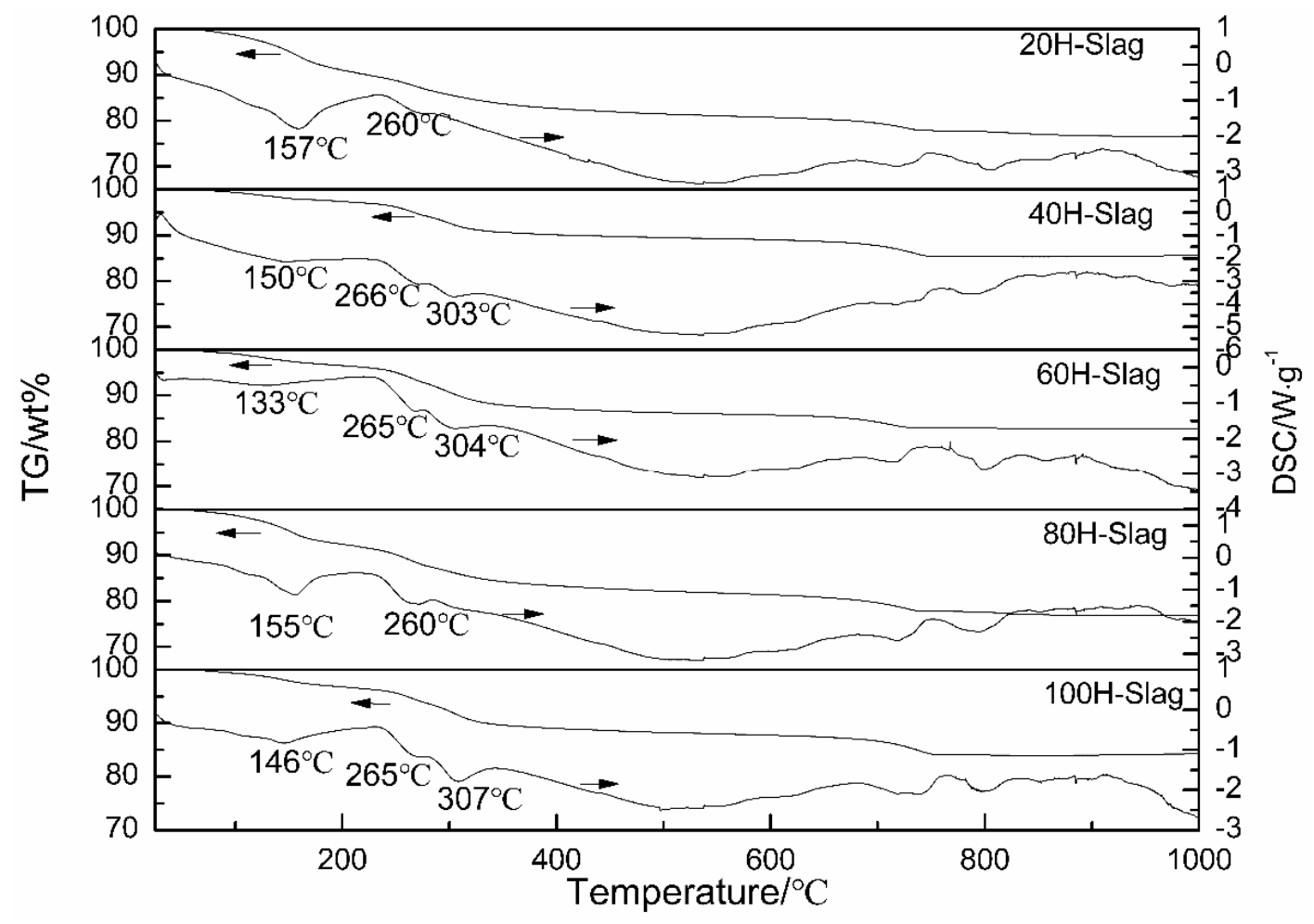

Figure 4. TG-DSC curves of the pretreated slags.

Table 3. The mass loss ratio of the pretreated slags between 105 and $800{ }^{\circ} \mathrm{C}$.

\begin{tabular}{cc}
\hline Sample & Mass Loss Ratio between $\mathbf{1 0 5}$ and $\mathbf{8 0 0}{ }^{\circ} \mathbf{C}(\mathbf{w t} \mathbf{\%})$ \\
\hline 20H-slag & 20.58 \\
40H-slag & 13.80 \\
60H-slag & 15.95 \\
80H-slag & 20.70 \\
100H-slag & 15.07 \\
\hline
\end{tabular}

In conclusion, cubic $\mathrm{C}_{3} \mathrm{AH}_{6}$ was a main hydration product for the $40 \mathrm{H}$-slag, $60 \mathrm{H}$-slag, and $100 \mathrm{H}$-slag. Part of $\mathrm{C}_{3} \mathrm{AH}_{6}$ could react with $\mathrm{CaCO}_{3}$ to generate $\mathrm{CCA}$ while the unreacted 
rhombohedral-shaped $\mathrm{CaCO}_{3}$ layer covered the slag surface, resulting in the hindrance of further hydration for these three slags. By contrast, flake-shaped $C_{4} A_{\bar{C}} H_{11}$ and $C_{3} A_{x}$ were the main hydration products for the $20 \mathrm{H}$-slag and the $80 \mathrm{H}$-slag, respectively, and their higher specific surface area may accelerate the carbonation reaction.

\subsection{Carbonation Efficiency of Slags Pretreated at Different Temperatures}

The XRD patterns of the slags after carbonation are shown in Figure 5. After carbonation, the peaks of $\mathrm{C}_{3} \mathrm{AH}_{\mathrm{x}}, \mathrm{C}_{4} \mathrm{~A} \overline{\mathrm{C}} \mathrm{H}_{11}$, and hydrocalumite disappeared or showed a significant decrease in intensity while the calcite peaks increased in intensity. This suggests the carbonation of these hydrates. On the contrary, $\mathrm{C}_{3} \mathrm{AH}_{6}$ appeared less active in terms of its carbonation, which may be the main cause of the less intense calcite peaks in the carbonated $100 \mathrm{H}$-slag with $\mathrm{C}_{3} \mathrm{AH}_{6}$ as the main hydration product (see Figure 1). In addition, residual $\mathrm{C}_{4} \mathrm{~A} \overline{\mathrm{C}} \mathrm{H}_{11}$ peaks were observed, indicating the incomplete carbonation of $\mathrm{C}_{4} \mathrm{~A}_{\mathrm{C}} \mathrm{H}_{11}$ in the $20 \mathrm{H}$-slag during carbonation. This resulted in the less intense calcite peaks in the carbonated $20 \mathrm{H}$-slag compared with the carbonated $80 \mathrm{H}$-slag.

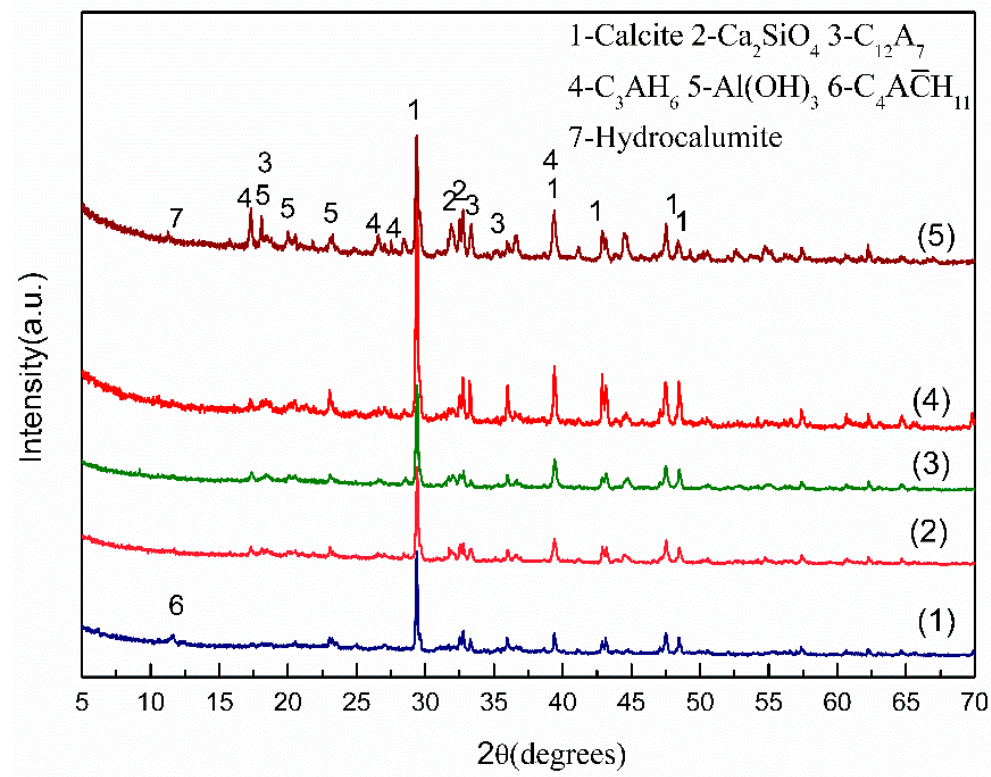

Figure 5. XRD patterns of (1) carbonated 20H-slag, (2) carbonated 40H-slag, (3) carbonated 60H-slag, (4) carbonated $80 \mathrm{H}$-slag, and (5) carbonated $100 \mathrm{H}$-slag.

Figure 6 exhibits the FESEM pictures of the slags after carbonation. For the carbonated $20 \mathrm{H}$-slag, flake-shaped $\mathrm{C}_{4} \mathrm{~A} \overline{\mathrm{C}} \mathrm{H}_{11}$ was decomposed and cubic calcite crystals were observable (Figure 6a). In the carbonated $40 \mathrm{H}$-slag and 60H-slag, some of the cubic calcite crystals were surrounded by unreacted hydrates (Figure $6 b, c$ ). Larger amounts of cubic calcite crystals appeared in the carbonated $80 \mathrm{H}$-slag than in the other slags, leading to the breakdown of continuous $\mathrm{C}_{3} \mathrm{AH}_{\mathrm{x}}$ gel (Figure $6 \mathrm{~d}$ ). Moreover, the carbonation products were covered by a small amount of unreacted $\mathrm{C}_{3} \mathrm{AH}_{\mathrm{x}}$ debris (Figure $6 \mathrm{~d}$ ). The microstructure of the carbonated $100 \mathrm{H}$-slag (Figure 6e) was similar to the carbonated $40 \mathrm{H}$-slag and $60 \mathrm{H}$-slag; it was composed of unreacted hydration products, unhydrated slag, and some cubic calcite crystals. In each of the slags, the cubic calcite was generated by the direct reaction of $\mathrm{CO}_{2}$ with the hydrates and amorphous $\mathrm{AH}$, as the other reaction product surrounded the cubic calcite crystals [11]. In each of the carbonated slags, calcite appeared as non-uniform aggregated crystal particles, which indicate direct carbonation [21]. Direct carbonation of alkaline slag involved two stages: $\mathrm{CO}_{2}$ dissolution and carbonation reaction [21,22]. The simplified direct carbonation mechanism of slags with hydrothermal pretreatment in this study was summarized in Table 4. 


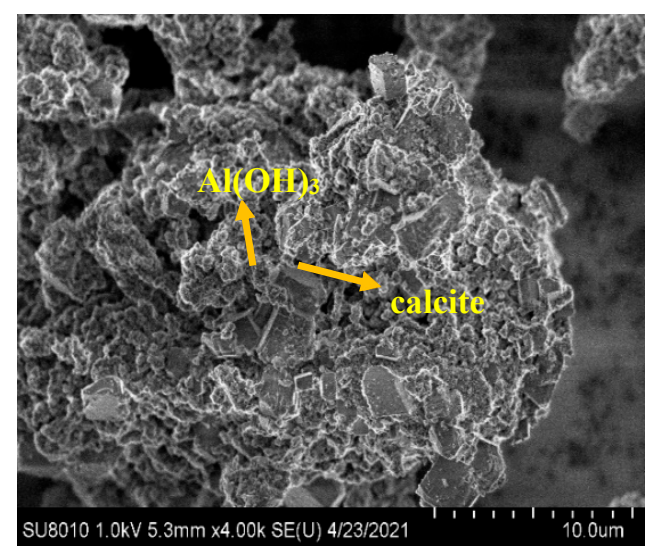

(a)

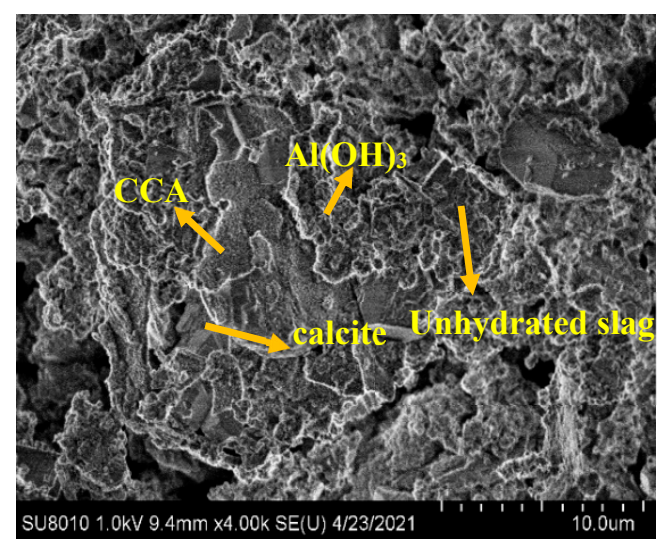

(c)

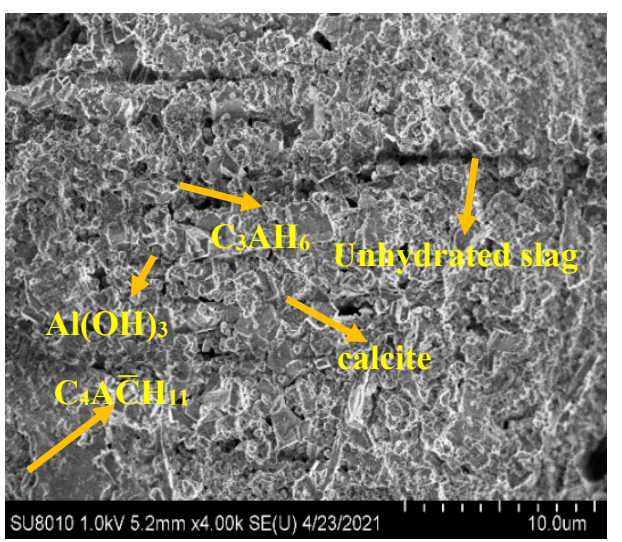

(b)

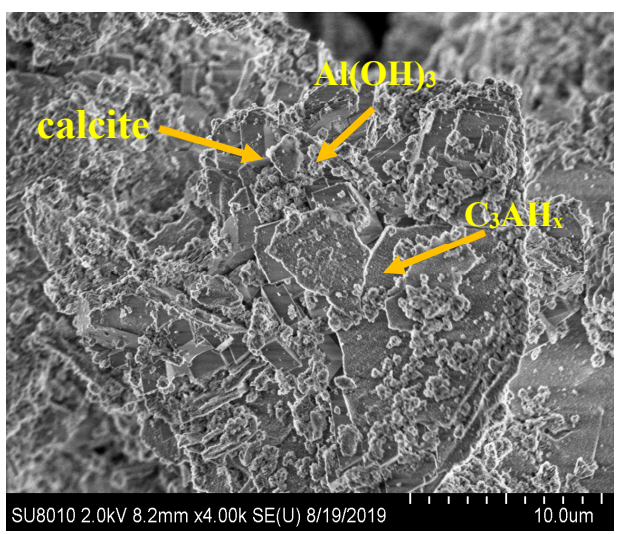

(d)

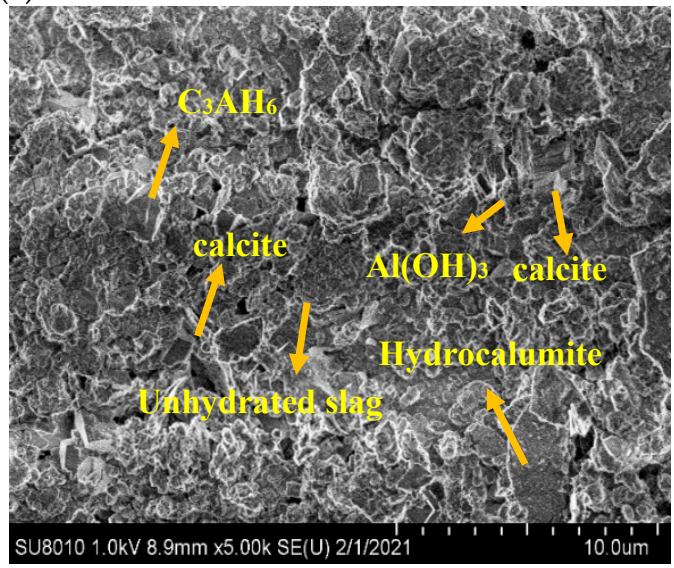

(e)

Figure 6. FESEM pictures of (a) carbonated 20H-slag, (b) carbonated 40H-slag, (c) carbonated $60 \mathrm{H}$-slag, (d) carbonated 80H-slag, and (e) carbonated 100H-slag.

Table 4. Chemical reaction equations of the direct carbonation of the pretreated slags in this study.

\begin{tabular}{|c|c|}
\hline Stage & Chemical Reaction Equation \\
\hline $\mathrm{CO}_{2}$ dissolution & $\begin{array}{l}\mathrm{CO}_{2(\mathrm{~g})} \rightarrow \mathrm{CO}_{2(\mathrm{aq})} \\
\mathrm{CO}_{2(\mathrm{aq})}+2 \mathrm{OH}^{-}{ }_{(\mathrm{aq})} \rightarrow \mathrm{CO}_{3}{ }^{2-}{ }_{(\mathrm{aq})}+\mathrm{H}_{2} \mathrm{O}_{(\mathrm{l})}\end{array}$ \\
\hline Carbonation & $\begin{array}{l}\mathrm{Ca}_{3} \mathrm{Al}_{2} \mathrm{O}_{6} \cdot 6 \mathrm{H}_{2} \mathrm{O}_{(\mathrm{s})}+3 \mathrm{CO}_{3}{ }^{2-}{ }_{(\mathrm{aq})} \rightarrow 3 \mathrm{CaCO}_{3(\mathrm{~s})}+2 \mathrm{Al}(\mathrm{OH})_{3(\mathrm{~s})}+6 \mathrm{OH}^{-}{ }_{(\mathrm{aq})} \\
\mathrm{Ca}_{3} \mathrm{Al}_{2} \mathrm{O}_{6} \cdot \mathrm{xH}_{2} \mathrm{O}_{(\mathrm{s})}+3 \mathrm{CO}_{3}{ }^{2-}{ }_{(\mathrm{aq})} \rightarrow 3 \mathrm{CaCO}_{3(\mathrm{~s})}+2 \mathrm{Al}(\mathrm{OH})_{3(\mathrm{~s})}+6 \mathrm{OH}^{-}{ }_{(\mathrm{aq})}+ \\
(\mathrm{x}-6) \mathrm{H}_{2} \mathrm{O}(\mathrm{l}) \\
3 \mathrm{CaO} \cdot \mathrm{Al}_{2} \mathrm{O}_{3} \cdot \mathrm{CaCO}_{3} \cdot 11 \mathrm{H}_{2} \mathrm{O}_{(\mathrm{s})}+3 \mathrm{CO}_{3}{ }^{2-}{ }_{(\mathrm{aq})} \rightarrow 4 \mathrm{CaCO}_{3(\mathrm{~s})}+2 \mathrm{Al}(\mathrm{OH})_{3(\mathrm{~s})}+ \\
6 \mathrm{OH}^{-}{ }_{(\mathrm{aq})}+5 \mathrm{H}_{2} \mathrm{O}(\mathrm{l})\end{array}$ \\
\hline
\end{tabular}


Based on the TG curves of the carbonated slags (Figure 7), $\mathrm{CO}_{2}$ uptake (wt\%) was calculated with Equation (1) where $\mathrm{m}$ was the dry weight at $325^{\circ} \mathrm{C}$ (at this temperature, free water and chemically bound water evaporated). The results of $\mathrm{CO}_{2}$ uptake were listed in Table 5. The $\mathrm{CO}_{2}$ uptake of slags followed this order: $80 \mathrm{H}$-slag $(13.66 \mathrm{wt} \%)>20 \mathrm{H}$-slag $(10.82 \mathrm{wt} \%)>60 \mathrm{H}$-slag $(9.83 \mathrm{wt} \%)>40 \mathrm{H}$-slag $(9.21 \mathrm{wt} \%)>100 \mathrm{H}$-slag $(6.84 \mathrm{wt} \%)$, which corresponded well with the XRD and FESEM results. This is attributed to the following reasons: (1) a dense $\mathrm{CaCO}_{3}$ or $\mathrm{AH}$ gel layer covered the unhydrated slag surface in the $40 \mathrm{H}$-slag and the $60 \mathrm{H}$-slag, therefore resulting in the hindrance of further hydration and carbonation; (2) flake-shaped hydrates such as $\mathrm{C}_{4} \mathrm{~A} \overline{\mathrm{C}} \mathrm{H}_{11}$ in the $20 \mathrm{H}$-slag or $\mathrm{C}_{3} \mathrm{AH}_{\mathrm{x}}$ in the $80 \mathrm{H}$-slag provided a larger reaction surface aera than the cubic $\mathrm{C}_{3} \mathrm{AH}_{6}$ and raw slag particles, avoiding calcite and $\mathrm{AH}$ gel layer formation on the unreacted hydrates surface. In short, the carbonation efficiency was strongly dependent on the type and morphology of the hydrates of LF slag.

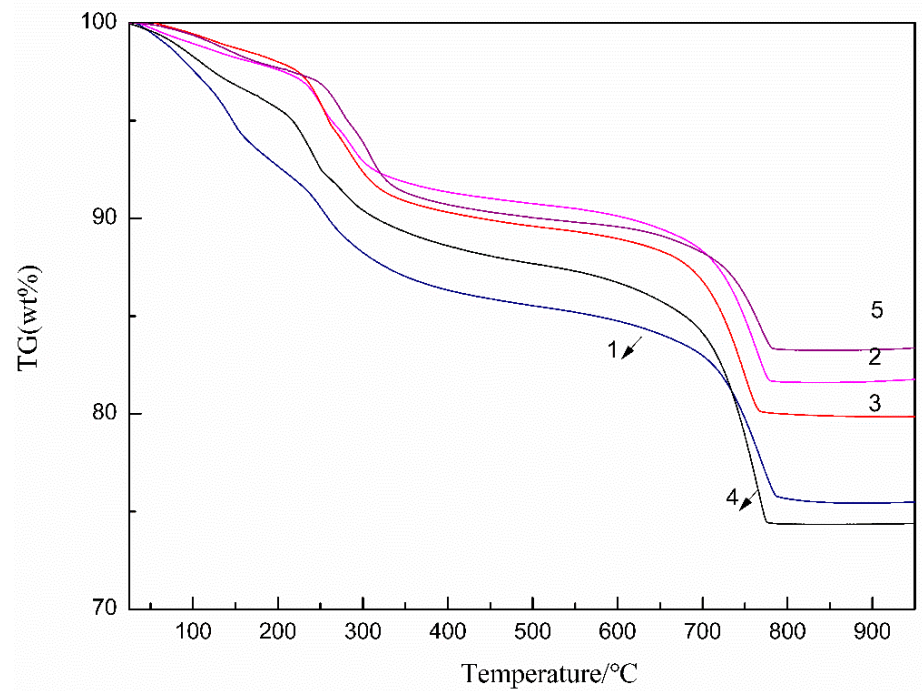

Figure 7. TG curves of (1) carbonated $20 \mathrm{H}-$ slag, (2) carbonated $40 \mathrm{H}$-slag, (3) carbonated $60 \mathrm{H}$-slag, (4) carbonated $80 \mathrm{H}$-slag, and (5) carbonated $100 \mathrm{H}$-slag.

Table 5. $\mathrm{CO}_{2}$ uptake of pretreated slags.

\begin{tabular}{cccccc}
\hline & 20H-Slag & 40H-Slag & 60H-Slag & 80H-Slag & 100H-Slag \\
\hline $\mathrm{CO}_{2}$ Uptake $(\mathrm{wt} \%)$ & 10.82 & 9.21 & 9.83 & 13.66 & 6.84 \\
\hline
\end{tabular}

The maximum $\mathrm{CO}_{2}$ uptake among these five pretreated slags was $13.66 \mathrm{wt} \%$ (namely $136.6 \mathrm{~g}$ of $\mathrm{CO}_{2} / 1 \mathrm{~kg}$ of slag) which was attained by the $80 \mathrm{H}$-slag. Compared with previous studies about wet direct carbonation of steelmaking slags conducted under ambient temperature and pressure (See Table 6), the $\mathrm{CO}_{2}$ uptake of the $80 \mathrm{H}$-slag in this study was considerable and the process was attractive. With an annual (2019-2020) output of LF slag of about $5 \mathrm{MT}$ in China, this waste could, under $80^{\circ} \mathrm{C}$ hydrothermal pretreatment, capture about $0.67 \mathrm{MT} \mathrm{CO}_{2}$ if the mineral carbonation process is applied in steel plants.

Table 6. Comparison of current with previous steelmaking slag carbonation studies conducted under ambient temperature and pressure.

\begin{tabular}{cclc}
\hline Slag Type & $\mathrm{CO}_{\mathbf{2}}$ Uptake (g of $\mathrm{CO}_{2} / \mathbf{1} \mathbf{~ k g}$ of Slag) & \multicolumn{1}{c}{ Conditions } & Reference \\
\hline \multirow{3}{*}{ Al-rich LF slag } & \multirow{3}{*}{136.6} & Temperature: $40^{\circ} \mathrm{C}$ & \\
& & S/W ratio: $1: 10$ & This study \\
& & Reaction time: $1 \mathrm{~h}$ & \\
\hline
\end{tabular}


Table 6. Cont.

\begin{tabular}{|c|c|c|c|}
\hline Slag Type & $\mathrm{CO}_{2}$ Uptake (g of $\mathrm{CO}_{2} / 1 \mathrm{~kg}$ of Slag) & Conditions & Reference \\
\hline EAF steel slag & 87 & $\begin{array}{l}\text { Temperature: } 20^{\circ} \mathrm{C} \\
\mathrm{S} / \mathrm{W} \text { ratio: } 1: 10 \\
\text { Reaction time: } 37 \mathrm{~min}\end{array}$ & [23] \\
\hline BOF steel slag & 116.4 & $\begin{array}{l}\text { Temperature: } 70{ }^{\circ} \mathrm{C} \\
\text { S/W ratio: } 1: 2 \\
\text { Reaction time: } 2 \mathrm{~h}\end{array}$ & [24] \\
\hline LF slag & 67 & $\begin{array}{l}\text { Temperature: } 20^{\circ} \mathrm{C} \\
\text { S/W ratio: } 1: 20 \\
\text { Reaction time: } 1 \mathrm{~h}\end{array}$ & [25] \\
\hline BOF steel slag & 168.32 & $\begin{array}{l}\text { Temperature: } 60^{\circ} \mathrm{C} \\
\text { S/W ratio: } 1: 30 \\
\text { Reaction time: } 10 \mathrm{~h}\end{array}$ & [26] \\
\hline LF slag & 56 & $\begin{array}{l}\text { Temperature: } 20^{\circ} \mathrm{C} \\
\mathrm{S} / \mathrm{W} \text { ratio: } 1: 5 \\
\text { Reaction time: } 70 \mathrm{~min}\end{array}$ & [27] \\
\hline BOF steel slag & 215 & $\begin{array}{l}\text { Temperature: } 60^{\circ} \mathrm{C} \\
\text { S/W ratio: } 1: 5 \\
\text { Reaction time: } 3 \mathrm{~h}\end{array}$ & [28] \\
\hline
\end{tabular}

\section{Conclusions}

This study investigated the temperature of hydrothermal pretreatment on the hydrate formation and carbonation efficiency of Al-rich LF slag at ambient temperature and pressure. The main results are as follows:

During hydrothermal pretreatment, cubic $\mathrm{C}_{3} \mathrm{AH}_{6}$ was a main hydration product for $40{ }^{\circ} \mathrm{C}, 80^{\circ} \mathrm{C}$, and $100{ }^{\circ} \mathrm{C}$-pretreated slags while $\mathrm{C}_{4} \mathrm{~A}_{\overline{\mathrm{C}}} \mathrm{H}_{11}$ and $\mathrm{C}_{3} \mathrm{AH}_{\mathrm{x}}$ with flaked shapes were the main hydrates for $20^{\circ} \mathrm{C}$ and $80^{\circ} \mathrm{C}$-pretreated slags, respectively. Rhombohedralshaped $\mathrm{CaCO}_{3}$ was generated by the reaction between $\mathrm{C}_{12} \mathrm{~A}_{7}$ in the slag and $\mathrm{CO}_{2}$ in the air; and then $\mathrm{CaCO}_{3}$ reacted with $\mathrm{C}_{3} \mathrm{AH}_{6}$ to form flake-shaped CCA. Flake-shaped products presented higher BET specific surface area. In $40^{\circ} \mathrm{C}, 60^{\circ} \mathrm{C}$, and $100{ }^{\circ} \mathrm{C}$-pretreated slags, a dense $\mathrm{CaCO}_{3}$ layer surrounded the unreacted core of the slag particle, resulting in the hindrance of further $\mathrm{C}_{12} \mathrm{~A}_{7}$ hydration.

Flake-shaped products could provide a lager reaction surface area and avoid the calcite and $\mathrm{AH}$ gel layer formation on the surface of the unreacted hydrates. Therefore, $80{ }^{\circ} \mathrm{C}$ and $20^{\circ} \mathrm{C}$-pretreated slags containing a larger number of flake-shaped hydrates had larger $\mathrm{CO}_{2}$ uptake (13.66 wt \% and $10.82 \mathrm{wt} \%$, respectively). Cubic $\mathrm{C}_{3} \mathrm{AH}_{6}$ crystal and unhydrated raw slag particles were less inactive for carbonation, resulting in the smaller $\mathrm{CO}_{2}$ uptake for $40{ }^{\circ} \mathrm{C}, 60^{\circ} \mathrm{C}$, and $100{ }^{\circ} \mathrm{C}$-pretreated slags $(9.21 \mathrm{wt} \%, 9.83 \mathrm{wt} \%$ and $6.84 \mathrm{wt} \%$, respectively). In short, the carbonation efficiency of the pretreated slag was strongly associated with the morphology of the hydration products and the hydration extent of LF slag.

Author Contributions: Investigation, Y.H.; resources, G.X.; writing-original draft preparation, G.X.; writing-review and editing, Y.H.; supervision, G.X.; funding acquisition, Y.H. Both authors have read and agreed to the published version of the manuscript.

Funding: This work was funded by the Natural Science Foundation of Hunan Province, China (Grant No. 2020JJ4157).

Data Availability Statement: The data presented in this study are available on request from the corresponding author. The data are not publicly available due to patent issues.

Acknowledgments: The authors thank the support from the Research Foundation of the Natural Science Foundation of Hunan Province, China (Grant No. 2020JJ4157).

Conflicts of Interest: The authors declare no conflict of interest. 


\section{References}

1. International Energy Agency. Global Energy \& $\mathrm{CO}_{2}$ Status Report: The Latest Trends in 2018; International Energy Agency: Pairs, France, 2019.

2. Sun, Y.; Yao, M.S.; Zhang, J.P.; Yang, G. Indirect $\mathrm{CO}_{2}$ mineral sequestration by steelmaking slag with $\mathrm{NH}_{4} \mathrm{Cl}$ as leaching solution. Chem. Eng. J. 2011, 173, 437-445. [CrossRef]

3. Rushendra Revathy, T.D.; Palanivelu, K. Direct mineral carbonation of steelmaking slag for $\mathrm{CO}_{2}$ sequestration at room temperature. Environ. Sci. Pollut. Res. 2016, 23, 7349-7359. [CrossRef] [PubMed]

4. Liu, W.Z.; Yin, S.; Luo, D.M.; Zhang, G.Q.; Yue, H.R.; Liang, B.; Wang, L.M.; Li, C. Optimizing the recovery of high-value-added ammonium alum during mineral carbonation of blast furnace slag. J. Alloys Compd. 2019, 774, 1151-1159. [CrossRef]

5. Rushendra Revathy, T.D.; Ramachandran, A.; Palanivelu, K. Sequestration of $\mathrm{CO}_{2}$ by red mud with flue gas using response surface methodology. Carbon Manag. 2021, 12, 139-151. [CrossRef]

6. Wang, Y.J.; Zeng, Y.N.; Li, J.G.; Zhang, Y.Z.; Zhao, Q.Z. Carbonation of argon oxygen decarburization stainless steel slag and its effect on chromium leachability. J. Clean. Prod. 2020, 256, 120377. [CrossRef]

7. Ho, H.J.; Lizuka, A.; Shibata, E. Utilization of low-calcium fly ash via direct aqueous carbonation with a low-energy input: Determination of carbonation reaction and evaluation of the potential for $\mathrm{CO}_{2}$ sequestration and utilization. J. Waste Manag. 2021, $288,112411$.

8. Liu, W.; Teng, L.; Rohani, S.; Qin, Z.; Zhao, B.; Xu, C.C.; Ren, S.; Liu, Q.; Liang, B. $\mathrm{CO}_{2}$ mineral carbonation using industrial solid wastes: A review of recent developments. J. Chem. Eng. 2021, 416, 129093. [CrossRef]

9. Ibrahim, M.H.; El-Naas, M.H.; Benamor, A.; Al-Sobhi, S.S.; Zhang, Z. Carbon mineralization by reaction with steel-making waste: A review. Processes 2019, 7, 115. [CrossRef]

10. Santos, R.M.; François, D.; Mertrn, G.; Elsen, J.; Gerven, T.V. Ultrasound-enhanced mineral carbonation. Appl. Therm. Eng. 2013, $157,109-116$.

11. Huang, Y.; Zeng, Z. Improvement of desulfurization efficiency of Al-rich ladle furnace refining slag with an aqueous carbonation method by hydrothermal or ultrasound pretreatment. Environ. Sci. Pollut. Res. 2021, 28, 27703-27711. [CrossRef]

12. Koplík, J.; Tomala, L.; Novotný, R. Hydration of calcium aluminate phases at different temperatures. Adv. Mater. Res. 2014, 1000, 24-27. [CrossRef]

13. Edmonds, R.N.; Majumdar, A.J. The hydration of $12 \mathrm{CaO} .7 \mathrm{Al}_{2} \mathrm{O}_{3}$ at different temperatures. Cem. Concr. Res. 1988, $18,473-478$. [CrossRef]

14. El-Naas, M.H.; Maisa, E.G.; Hameedi, S.; Mohamed, A.-M.O. $\mathrm{CO}_{2}$ sequestration using accelerated gas-solid carbonation of pre-treated EAF steel-making bag house dust. J. Environ. Manag. 2015, 156, 218-224.

15. Wang, Z.P.; Yang, H.Y.; Zhao, Y.T.; Lu, L.L.; Jia, D.L. Delaying Effect of $\mathrm{NaCl}$ on the conversion of hydrates of calcium aluminate cement. In Proceedings of the 11th International Conference on High-Performance Ceramics, Kunming, China, 25-29 May 2019.

16. Ewa, L.; Dominika, M. Structure, microstructure and thermal stability characterizations of $\mathrm{C}_{3} \mathrm{AH}_{6}$ synthesized from different precursors through hydration. J. Therm. Anal. Calorim. 2020, 139, 1693-1706.

17. Liu, W.; Zhang, H.; Zhou, Q.S.; Peng, Z.H.; Qi, T.G.; Li, X.B.; Liu, G.H. Reaction tricalcium aluminate hexahydrate $\left(\mathrm{C}_{3} \mathrm{AH}_{6}\right) \mathrm{with}$ carbon dioxide. J. Cent. South Univ. 2011, 42, 595-598.

18. Xiao, J.; Gou, F.; Jin, Y.G.; Wang, Y.H. Effect of $\mathrm{CaCO}_{3}$ on hydration characteristics of $\mathrm{C}_{3}$ A. J. Cent. South Univ. Technol. 2010, 17, 918-923. [CrossRef]

19. Luz, A.P.; Pandolfelli, V.C. $\mathrm{CaCO}_{3}$ addition effect on the hydration and mechanical strength evolution of calcium aluminate cement for endodontic applications. Ceram. Int. 2012, 38, 1417-1425. [CrossRef]

20. Feng, Y.B.; Tang, C.M.; Qiu, T. Effect of ball milling and moderate surface oxidization on the microwave absorption properties of FeSiAl composites. Mater. Sci. Eng. B 2013, 178, 1005-1011. [CrossRef]

21. Sun, Y.; Yang, G.; Li, K.; Zhang, L.C.; Zhang, L. $\mathrm{CO}_{2}$ mineralization using basic oxygen furnace slag: Process optimization by response surface methodology. Environ. Earth. Sci. 2016, 75, 1335. [CrossRef]

22. Yi, Y.R.; Han, M.F. The reactivity of carbon dioxide capture with calcium-based waste solid by wet process. J. China Coal Soc. 2012, 37, 1205-1210.

23. Uibu, M.; Kuusik, R.; Andreas, L.; Kirsimäe, $\mathrm{K}$. The $\mathrm{CO}_{2}$-binding by Ca-Mgsilicates in direct aqueous carbonation of oil shale ash and steel slag. Energy Procedia 2011, 4, 925-932. [CrossRef]

24. Wang, C.Y.; Bao, W.J.; Guo, Z.C.; Li, H.Q. Carbon Dioxide Sequestration via Steelmaking Slag Carbonation in Alkali Solutions: Experimental Investigation and Process Evaluation. Acta Metall. Sinica 2018, 31, 771-784. [CrossRef]

25. Paris, K.A.; Hills, C.D.; Maries, A.; Gunning, P.J.; Wray, D.S. Enhancement of accelerated carbonation of alkaline waste residues.by ultrasound. Waste Manag. 2016, 50, 121-129.

26. Chen, Z.M.; Li, R.; Zheng, X.M.; Liu, J.X. Carbon sequestration of steel slag and carbonation for activating RO phase. Cem. Concr. Res. 2021, 139, 106271. [CrossRef]

27. Yi, Y.R.; Lin, Y.; Du, Y.C.; Bai, S.Q.; Ma, Z.L.; Chen, Y.G. Accelerated carbonation of ladle furnace slag and characterization of its mineral phase. Cem. Concr. Res. 2021, 276, 122235.

28. Chen, K.W.; Pan, S.Y.; Chen, C.T.; Chen, Y.H.; Qiang, R.C. High-gravity carbonation of basic oxygen furnace slag for $\mathrm{CO}_{2}$ fixation and utilization in blended cement. J. Cleaner Prod. 2016, 124, 350-360. [CrossRef] 